\title{
Bilingualism and the Brain
}

\author{
Nazlı AĞGÜN ${ }^{1}$
}

Citation/@: Ağgün, N. (2021). Bilingualism and the Brain. Artuklu Human and Social Science Journal, 6(2), 138- 144.

\begin{abstract}
Bilinguals have been compared with monolinguals and become research focus due to their more extensive communication skills, more complex thought processes, and easier identity development in two different languages. Being a bilingual from babyhood is a unique experience which can change the structure, the network and the executive control system in the brain. There are two constantly active languages in the minds of bilinguals and bilinguals are always in a state of deciding between these languages, which is an exercise for the brain. A study (Mechelli, 2004) has showed that that second-language learning raises grey matter in the left inferior parietal cortex, which is related to decision-making, inhibition and focusing. In fact, the difference between bilinguals and monolinguals could emerge at infanthood. A relevant study (Kovacs et al., 2009) has indicated that seven-month-year-olds bilinguals have left the contemporaneous monolinguals behind at learning a new rule while playing with puppets. Furthermore, bilinguals have advantages at getting Alzheimer at elder ages. The difference between monolinguals and bilinguals for getting the illness is 4.1 years (Bialstok et al., 2007). Based on the results of the relevant studies, it can be concluded that bilingualism and multilingualism should be encouraged across the world for cognitive advantage and conserving good health.
\end{abstract}

Key Words: Bilinguals, monolinguals, brain, language.

\footnotetext{
${ }^{1}$ Öğretim Görevlisi, Nazlı Ağgün,Osmaniye Korkut Ata Üniversitesi/Fen-Edebiyat Fakültesi, nazliaggun@ @mail.com, ORCID: 0000-0002-2705-109X.
}

Geliş/Received: 20 Kasım 2021, Kabul/Accepted: 20 Aralık 2021 


\title{
İki Dillilik ve Beyin
}

\author{
Nazlı AĞGÜN
}

Atıf/C: Ağgün, N. (2021). İki Dillilik ve Beyin. Artuklu İnsan ve Toplum Bilim Dergisi, 6(2), $138-144$.

$\ddot{\mathbf{O z}}$

İki dilliler, daha kapsamlı iletişim becerileri, daha karmaşık düşünce süreçleri ve iki farklı dilde daha kolay kimlik gelişimi sayesinde tek dillilerle karşılaştırılmış ve araştırma odağı haline gelmiştir. Bebeklikten iki dilli olmak, beyindeki yapıyı, ağı ve yönetici kontrol sistemini değiştirebilecek eşsiz bir deneyimdir. İki dillilerin zihninde sürekli aktif iki dil vardır ve iki dilliler her zaman bu diller arasında karar verme durumundadır, bu da beyin için bir egzersizdir. Bir çalışma (Mechelli, 2004), ikinci dil öğreniminin, karar verme, inhibisyon ve odaklanma ile ilgili olan sol alt parietal korteksteki gri maddeyi yükselttiğini göstermiştir. Aslında, iki dilli ve tek dilli arasındaki fark bebeklikte ortaya çıkabilir. İlgili bir çalışma (Kovacs ve ark. 2009), yedi aylık iki dilli çocukların kuklalarla oynarken yeni bir kural öğrenmede aynı yaştaki tek dillileri geride bıraktıklarını belirtmiştir. Ayrıca, iki dile de hâkim kişilerin, daha ileri yaşlarda Alzheimer hastalığına daha geç yakalanma gibi bir avantajı da var. Tek dilli ve iki dilli arasındaki hastalığa yakalanmak yaşı arasındaki fark 4,1 yıldır (Bialstok ve ark., 2007). İlgili çalışmaların sonuçlarına dayanarak bilişsel avantaj ve sağlığın korunması için dünya genelinde iki dillilik ve çok dilliliğin teşvik edilmesi gerektiği sonucuna varılabilir.

Anahtar kelimeler: İki dillilik, tek dilliler, beyin, dil. 


\section{Introduction}

Monolinguals are the individuals that are proficient at speaking one language, sometimes with its dialect or accent. On the other hand, bilinguals are individuals that are proficient at speaking two languages. Similarly, multilinguals are the ones that speak three or more languages. According to Census Bureau (2010), more than half of the world speak more than one language. Languages in the world are still changing very fast due to demographic trends, the latest technology and contact with the rest of the world.

Although the phenomena of being a bilingual or multilingual has always been a part of human being, it has not been received as positively all the time. As an example, challenging the idea of monolingualism in the western counties is quite difficult because the main language in the country has got a symbolic meaning as language is perceived very emotionally and ideologically. A leading Christian Democrat in Germany, Peter Muller emphasis the need to pass German tests to get residency and goes on saying "This act is an act for restricting immigration. It puts an end to the idea that Germany can be transformed into a multicultural immigration society" (as cited in Stevenson\&Schanze, 2009). Another challenge related to bilinguals is accommodation of students at the schools. To illustrate, California has got 1.5 million students who speak Spanish as their mother tongue mostly in K-12 public schools. The educators in that state are expected to teach these students in English, assist the students do well in the exams and not to stay behind of the other schools if they want to get funding.

On the other hand, there have been researchers from linguistic, cognitivist and social fields that have become interested in the concept of bilingual in a more positive way. Since bilinguals have got two different language systems in their brain, consisting of two different phonology, grammar, and pragmatics, does it mean they have cognitive advantages over monolinguals? Ramírez-Esparza \& Ikizer, (2017) found that bilinguals have advantages at switching and attuning easily in different contexts, and recognizing the tips in the social environment in an accurate way. The literature has also revealed further evidence that shows bilinguals have better attention and inhibition in executive control tests and keep these advantages even at older ages.The current literature review focuses on the studies done to understand the cognitive advantages of bilinguals. The review is important in term of understanding that the concept of speaking two or more languages is not limited with the issues such as immigrants, residency, or school accommodation. The concept deserves further reading, research, and thoughts to cherish cognitive advantages of bilinguals and to benefit from them as a country.

\section{Bilingualism and the Brain}

Bilingualism recently has attracted much attention in sociolinguistics, psycholinguistics, neurobiology, and politics due to the increasing multilingualism caused by globalization. It is estimated that sixty-six percent of the world as children are taught early-on to speaking two languages (Associated Press, 2001). Hence, it is difficult to ignore the concept of bilingualism and, accordingly, more studies have been conducted to illuminate the concept of bilingualism and to differentiate it from monolingualism. 
Bilinguals are admired by monolinguals for their ability to maintain two separate language syntaxes, pronunciations, vocabularies and pragmatics in their minds and to utilize the appropriate language system according to context. Bilinguals are envied for their more extensive communication skills, more complex thought processes, and easier identity development in two different languages. In addition to these more obvious perks of bilingualism, recent studies on language and neurolinguistics have shown that bilinguals are able to distinguish different languages from infancy, to have a better executive control system during all life spans and to have more resistance to illness such as Alzheimer and dementia.

Bilinguals have two constantly active languages in their minds and they always need to control and choose from them accordingly. In one research (Marian \& Spivey, 2003), it has been found that when an individual hears "can", words such as "candy" and "candle" activate in the brain as well. In the case of bilinguals, the words in both languages activate in the brain. Bilinguals constantly must control two languages since the non-target language could interfere with the target language and this would result in a problematic communication. Another study on code-switching has investigated the active parts in the brain regions with meta-analysis method scanning ten studies (Luk et al., 2012). The active parts in the brain are left inferior frontal gyrusb pars triangularis, left middle temporal gyrus, midline presupplementary motor area, left inferior frantal gyrus pars orbitalis, bilateral caudate nuclei and right precentral gyrus. Four of these parts are also responsible for the executive control system in the brain. A similar study (Hernandez et al., 2001) on code-switching and brain activation has used functional magnetic resonance imagining to follow the activation in the brain. It has been found that the dorsolateral prefrontal cortexwhich is also responsible for attention and inhibition in the brain - is active in bilinguals. Lastly, Mechelli and her colleagues (2004) have demonstrated that second-language learning increases grey matter in the left inferior parietal cortex. They suggest a possible relationship between the grey matter and performance. Based on the results of these studies, it can also be inferred that bilinguals utilize areas of the brain which are responsible for decision-making, inhibition and focusing. This means that bilinguals have advantages in their executive control systems since they continually make use of these systems.

Evidence for the superiority of bilinguals over monolinguals in inhibition and learning has been reported in a number of studies. A better executive control system and, as a result, better inhibition and learning skills for bilinguals may begin as early as during infancy. Mehler et al. (1988) found that newborn babies could recognize their mother tongue and exhibit preference for languages. Kovacs et al. (2009) extended the research on infants and language by conducting an experiment with seven-month-year-olds. In the first phase of the experiment, both monolingual and bilingual infants successfully learned that a puppet appeared on the one side of a computer's screen after they had heard a speech or visual cue. In the next phase, the puppet appeared on the opposite side of the screen and the infants were supposed to change the direction of their gaze after hearing a speech or visual cue. However, only the bilingual infants could discern the new rule and change the direction of their gazes to locate the puppet..

Ellen Bialstok and her colleagues have focused their research on bilingualism and its benefits for children, adults and elderly people. One of their studies (Bialstok et al., 
2008) aims to determine whether there is any difference between monolinguals and bilinguals in performing tasks requiring use of the executive control system. In the control condition, both monolinguals and bilinguals read the names of colors which were painted with their corresponding colors (e.g. the word "blue" appeared in the font color blue). In the interference condition, monolinguals and bilinguals read the names of colors that were painted with another color's name. (e.g. the word "blue" appeared in red font). Bilinguals out-performed monolinguals on the task. Based on these results, it can be inferred that bilinguals use their executive control systems more efficiently than monolinguals do.

In another experiment (Bialystok et al., 2004) whose goal is to determine whether or not bilingualism benefits the brain, the Simon Effect has been used. The participants are told that they are going to see a red square or a green square on the computer screen. If they see a red square, they should press the button on the left, which is a simple task. This task requires congruent thinking, which means being in harmony. On the other hand, when they see a green square, they should press the button on the right, which is a more difficult task since it requires incongruent thinking which means conflict. In the conflict situation, they should go to one side but they have to override that instinct in order to press the correct button, a task which takes time. The time that it takes to press the button is called the Simon Effect. Higher time means worse performance. The results showed that there is no difference between monolinguals and bilinguals in childhood, adulthood and adolescence but there is a difference in elder ages. Bilinguals outperform the monolinguals in middle age.

One of the important benefits of bilingualism for older individuals is protecting them from some diseases such as Alzheimer and Dementia. In its website, the National Institute on Aging (NIA) defines Dementia as "a brain disorder that affects communication and performance of daily activities" and Alzheimer's as "a form of dementia that specifically affects parts of the brain that control thought, memory and language." In a study on these illnesses (Bialstok et al., 2007), the authors have used the records of monolingual and bilingual patients in hospitals that are matched on demographic information, education and the degree of the illness. The results revealed that monolinguals possessed longer year of education compared to bilinguals. Nevertheless, monolinguals were 71.4 years old on average while bilinguals were 75.5 years old on average when they got the disease for the first time. The difference between monolinguals and bilinguals for developing the disease was 4.1 years. One more recent study by Schweizer et al. (2012) extended the research on bilingualism and dementia. It analyzed and compared tomography scans of monolingual and bilingual patients who had been matched based on lifestyle agents and found that bilinguals developed more antrophy in the medial temporal lobe, an area which is linked to Alzheimer's pathology.

Different from the studies above, a study (Hope et al., 2015) comparing language outcomes in monolingual and bilingual stroke patients revealed results in favor of monolinguals. The stroke patients suffered from language impairment or aphasia and they would lie to re-obtain this learning skill. In the trails, the patients were asked to read single sentences and repeat full sentences. In that study, monolinguals outperformed the bilinguals. The authors of the study interpreted this finding with the network in the brain. When the network for the cognitive control of language gets harmed, it means there is a 
damage in a larger area since the network in the bilinguals are more linked to each other. This could be the reason for a more difficult recover.

\section{Conclusion}

In conclusion, there is substantial evidence that both languages are active all the time and bilinguals choose from them during code-switching. Consequently, bilinguals are claimed to have better executive control system due to constant practice they do with languages since infancy. Studies have supported that bilinguals are better at memory, learning and inhibitions compared to monolinguals. Furthermore, bilinguals are found to have Alzheimer at elder ages.

Some implication could be made from the studies showing the benefits of bilingualism. To begin with, bilinguals or multilingual are not argued to be smarter than monolinguals in life. However, it needs to be known that speaking two languages from babyhood is a unique and special experience that can change the structure, the network and the executive control system in the brain and give some advantages. Hence, bilingualism and multilingualism should be cherished and supported with education system across the world. Also, bilingualism could save the countries from 5 years of cognition loss. Finally, instructors, families and educators should be informed about the way bilinguals show itself in behavior. The bilingual children who have less vocabulary knowledge or are slower at uttering sentences should not be categorized as less intelligent than monolinguals because it only means that the way bilinguals brain work is different and needs space. 


\section{Bilingualism and the Brain}

\section{References}

Associated Press. Some facts about the world's 6,800 tongues. 2001. Retrieved October 1,2012, from http://articles.cnn.com/2001-06-19/us/language.glance_1_languagesorigin-tongues?_s=PM:US

Bialystok, E., Craik, F. I., \& Freedman, M. (2007). Bilingualism as a protection against the onset of symptoms of dementia. Neuropsychologia. C. 45, S. 2, s. 459-464.

Bialystok, E., Craik, F. I., Klein, R., \& Viswanathan, M. (2004). Bilingualism, aging, and cognitive control: evidence from the Simon task. Psychology and aging, C. 19, S. 2, s. 290

Bialystok, E., Craik, F., \& Luk, G. (2008). Cognitive control and lexical access in younger and older bilinguals. Journal of Experimental Psychology: Learning, memory, and cognition, C. 34, S. 4, s. 859.

Hernandez, A. E., Dapretto, M., Mazziotta, J., \& Bookheimer, S. (2001). Language switching and language representation in Spanish-English bilinguals: An fMRI study. NeuroImage, C. 14, S. 2, s. 510-520.

Hope, T. M., Parker Jones, Ō., Grogan, A., Crinion, J., Rae, J., Ruffle, L., ... \& Green, D. W. (2015). Comparing language outcomes in monolingual and bilingual stroke patients. Brain, C. 138, S. 4, s. 1070-1083.

https://www.nia.nih.gov/health/alzheimers

Kovács, Á. M., \& Mehler, J. (2009). Cognitive gains in 7-month-old bilingual infants. Proceedings of the National Academy of Sciences, C. 106, S. 16, s. 6556-6560.

Luk, G., Green, D. W., Abutalebi, J., \& Grady, C. (2012). Cognitive control for language switching in bilinguals: A quantitative meta-analysis of functional neuroimaging studies. Language and cognitive processes, 27(10), 1479-1488. C. 14, S. 2, s. 510-520.

Marian, V., \& Spivey, M. (2003). Bilingual and monolingual processing of competing lexical items. Applied Psycholinguistics, C. 24, S. 2, s. 173-193.

Mechelli, A., Crinion, J. T., Noppeney, U., O'Doherty, J., Ashburner, J., Frackowiak, R. S., \& Price, C. J. (2004). Structural plasticity in the bilingual brain. Nature, C. 431, S. 7010, s. 757.

Mehler, J., Jusczyk, P., Lambertz, G., Halsted, N., Bertoncini, J., \& Amiel-Tison, C. (1988). A precursor of language acquisition in young infants. Cognition, C. 29, S. 2, s. 143178.

Schweizer, T. A., Ware, J., Fischer, C. E., Craik, F. I., \& Bialystok, E. (2012). Bilingualism as a contributor to cognitive reserve: Evidence from brain atrophy in Alzheimer's disease. cortex, C. 48, S. 8, s. 991-996. 